\title{
Heterosis for Growth in Reciprocal Crosses of Highly Inbred Lines of Japanese Quail
}

\author{
Katsunori Sato, Hiroyuki Fukuda, Yoshizane MaEda* \\ Yanuarso Eddy Hedianto and Takayoshi InO \\ Faculty of Agriculture, Okayama University, Okayama-shi, 700 \\ ${ }^{*}$ Faculty of Agriculture, Kagoshima University, Kagoshima-shi, 890
}

\begin{abstract}
Heterosis effect for growth of crossbreds between highly inbred lines of Japanese quail was examined. Materials consisted of two inbred lines (OO and $\mathrm{TT}$ ), their reciprocal crosses (TO and OT) and a randombred population. Two inbred lines were established by consecutive full-sib mating through 12 generations $(\mathrm{F}=0.925)$. Crossbreds were obtained from the reciprocal crosses (TO : TT males $\times \mathrm{OO}$ females and OT : OO males $\times$ TT females). Chicks were hatched and bred according to the usual methods practiced at Okayama University. Individual chicks were weighted at weekly intervals up to 16 weeks of age. Gompertz growth curves were applied to analyze the differences in growth traits among the five quail groups mentioned above.

Heterosis effect for growth was observed in the line crosses throughout the growth period. Heterosis effect in the early growth period (1 to 5 weeks of age for males and 2 to 7 weeks for females) was especially remarkable but not found at 0 week (hatching time). A difference in female body weight was observed between the crossbreds, TO and OT. This difference was considered to be partly due to maternal effect. Analysis with the Gompertz growth curve showed that the growth rate of the crossbreds was higher than that of the original inbred lines throughout the growth period.
\end{abstract}

(Jpn. Poult. Sci., 26: 93-100, 1989)

Key words : heterosis, growth, reciprocal cross, inbred line, Japanese quail

\section{Introduction}

It is well known that large heterosis effect appears in crosses between the inbred lines of domestic fowl and it has been practically applied to both egg and broiler production. Heterosis for growth has been observed in crossbreds between inbred lines of chickens ${ }^{1-7)}$. Although MAEDA et al. ${ }^{8)}$ studied heterosis for body weight at 3,6 and 12 weeks of age in Japanese quail, there has been no detailed study on heterosis for growth throughout the growing period.

This study was carried out to estimate heterosis effect for growth in reciprocal crosses between highly inbred lines of Japanese quail.

\section{Materials and Methods}

Two inbred lines (lines OO and TT), their reciprocal crosses (TO and OT) and a randombred population of Japanese quail were used in this study. Origins and

(Received Jul. 4, 1988) 
characteristics of these stocks have been described in the previous report ${ }^{9)}$. Two inbred lines were established by consecutive full-sib mating through 12 generations $(\mathrm{F}=0.925)$. The reciprocal crosses ( $\mathrm{TO}$ and $\mathrm{OT}$ ) were performed by pair matings between TT males and $\mathrm{OO}$ females and between $\mathrm{OO}$ males and TT females. Eggs laid during 12 to 15 weeks of parental age were incubated three times at 7-day intervals. Newly hatched chicks were brooded in a commercial 4-deck battery brooder for chickens under continuous light and a constant temperature of $32 \pm 2^{\circ} \mathrm{C}$. At 30 days of age, chicks were transferred to a house provided with 14 hours of light daily. Water and food containing $24 \%$ protein were provided continuously. Body weights (grams) were measured at hatching and thereafter at weekly intervals up to 16 weeks of age. The number of birds used in inbred lines OO and TT, reciprocal line crosses TO and OT and the randombred line was 17, 22, 42, 53 and 55, respectively for males and 22, 27, 51, 54 and 50, respectively for females. Gompertz growth curves were applied to analyze the differences in growth among the five populations mentioned above.

Statistical analysis of data was performed by the methods of SNEDECOR and CochraN ${ }^{10)}$. Heterosis effect was estimated as the percentage deviation of the means of crossbreds from those of the parental inbred lines.

\section{Results}

Fig. 1 shows growth curves of the males from the five populations from 0 to 16 weeks of age. The two inbred lines showed a linear increase in body weight up to 7 weeks of age and slower increases at subsequent ages. Their growth patterns were similar and there was no significant difference in body weight between the two inbred lines at any age. Conversely, the crossbreds (TO and OT) showed rapid increase in body weight up to 6 weeks and a slower increase at later ages. Body weight of OT was slightly higher than that of TO after 6 weeks of age. These crossbreds were superior to both of the inbred lines. The differences in body weight between the crossbreds and inbred lines were statistically significant except for the 0 week (hatching time). These differences tended to increase with age up to 6 weeks and to be relatively constant at subsequent ages. Randombreds showed the best growth among the five populations examined.

Fig. 2 shows growth curves of the females from 0 to 16 weeks of age. Body weight of the inbred lines increased linearly up to 8 weeks of ages. Body weight of inbred line TT was significantly higher than that of inbred line OO except at hatching and 1 week of age. The body weight of crossbreds increased rapidly up to 6 weeks and gradually thereafter. OT showed a higher body weight than TO after 4 weeks of age ; at 9, 10 and 11 weeks, the difference was statistically significant. The crossbreds were consistently superior to both of the inbred lines and the difference in body weight was significant except for the 0 week $(\mathrm{P}<0.05)$. On the other hand, the crossbreds were inferior to the randombred group ; difference was significant at any age except 0,8 and 9 weeks $(\mathrm{P}<0.05)$.

Heterosis effects for growth of the crossbreds were presented in Table 1. TO and 


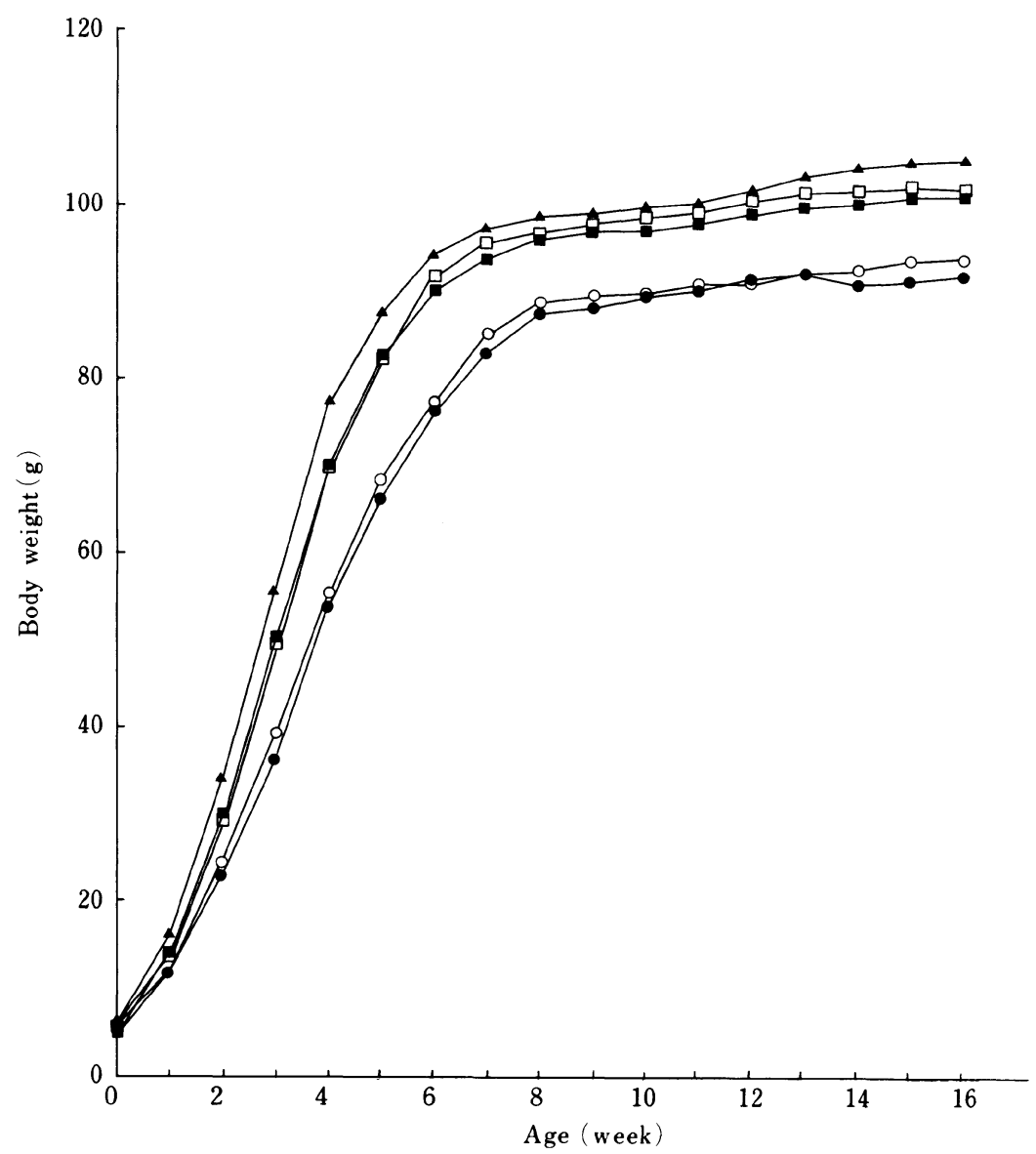

Fig. 1. The male growth curve in inbred lines, their reciprocal crosses and randombred population.

: Okayama inbred line (OO), $\bigcirc-\bigcirc$ : Toyohashi inbred line (TT),

: Toyohashi inbred line $\left(\sigma^{7}\right) \times$ Okayama inbred line ( + ) (TO),

: Okayama inbred line $\left(\sigma^{\pi}\right) \times$ Toyohashi inbred line (ㅇ) (OT),

$\Delta \quad \mathbf{\Delta}$ : Randombred population (RB).

OT showed negative values at 0 week. However, they showed greater heterosis at 1 to 5 weeks for males and at 2 to 7 weeks for females, indicating the values over 20 percentage.

Table 2 shows the parameter values of the Gompertz growth curve for the five populations. The parameter values of $\mathrm{A}$ (maximum size) and $\mathrm{k}$ (proportionality constant) were significantly higher in the crossbreds and the randombred population than in inbred lines, with the exception of the A value for female in TO. Age at inflexion point was significantly lower in the crossbreds and the randombred population than in the inbred lines. Moreover, body weight at inflexion point showed higher values in the crossbreds and randombreds. 


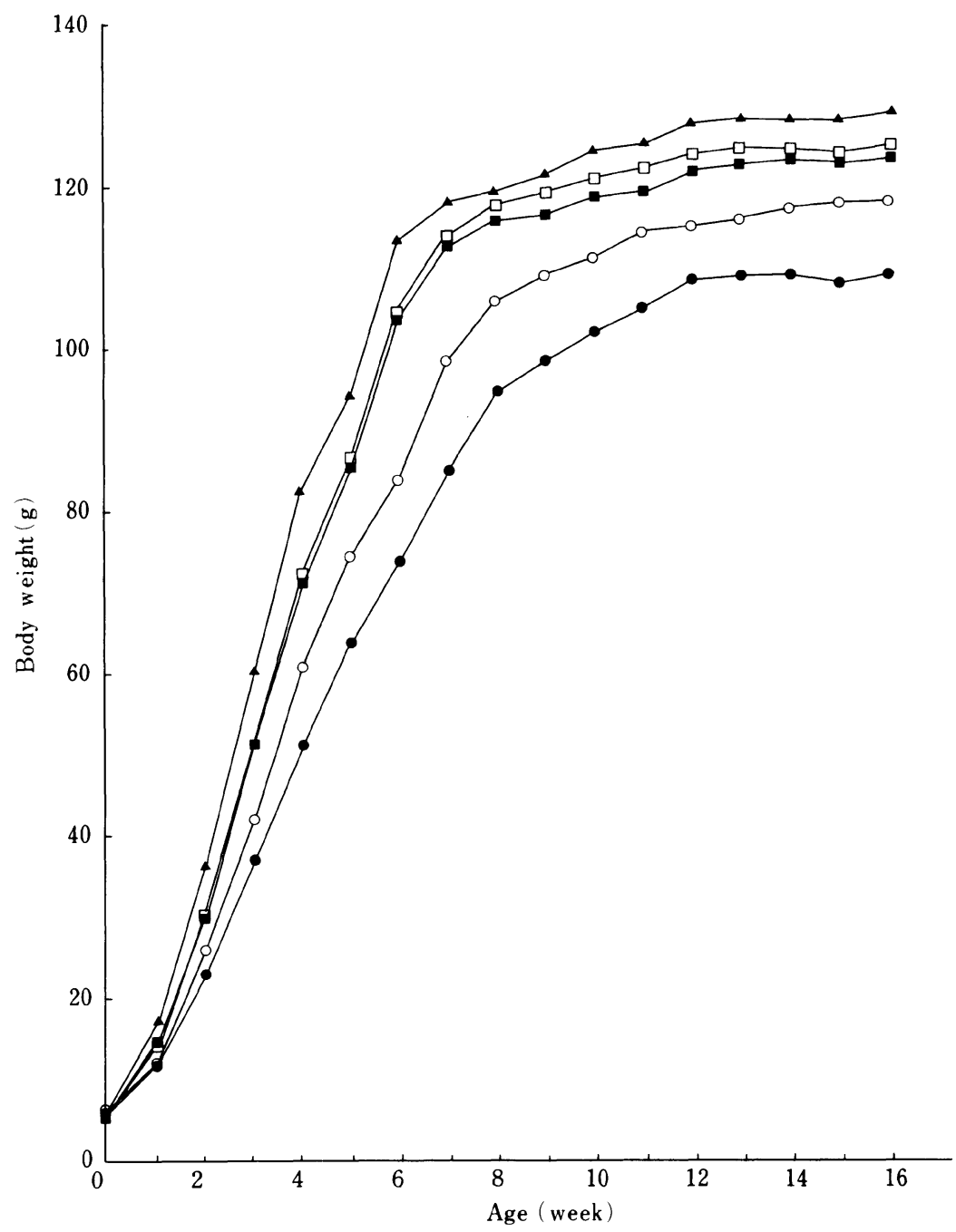

Fig. 2. The female growth curve in inbred lines, their reciprocal crosses and randombred population.

- O : Okayama inbred line $(\mathrm{OO}), \bigcirc-\bigcirc$ : Toyohashi inbred line (TT),

- Toyohashi inbred line $\left(\sigma^{7}\right) \times$ Okayama inbred line (우) (TO),

$\square-\square$ : Okayama inbred line $\left(\sigma^{T}\right) \times$ Toyohashi inbred line (우) (OT),

$\boldsymbol{\Delta} \boldsymbol{\Delta}$ : Randombred population (RB).

\section{Discussion}

In this study, heterosis effect for growth was found in reciprocal crosses between the highly inbred lines of Japanese quail. MAEDA et al. ${ }^{8)}$ have also observed heterosis for body weight at 3,6 and 12 weeks of age in crosses of highly inbred lines of Japanese quail. In crosses between inbred lines of chickens ${ }^{1-7}$, heterosis for growth rate and body weight was observed. Our data are in agreement with these reports. We observed a greater heterosis effect for growth in the early growth period (1 to 5 
Table 1 Estimate of heterosis effects in percentage for the growth in the reciprocal crosses ${ }^{1)}$

\begin{tabular}{|c|c|c|c|c|}
\hline \multirow{3}{*}{$\begin{array}{c}\text { Age } \\
(\text { week) }\end{array}$} & \multicolumn{4}{|c|}{ Heterosis percentage ${ }^{2)}$} \\
\hline & \multicolumn{2}{|c|}{ Male } & \multicolumn{2}{|c|}{ Female } \\
\hline & TO & OT & TO & OT \\
\hline 0 & -5.6 & -4.0 & -4.7 & -3.1 \\
\hline 1 & 23.4 & 20.9 & 17.4 & 15.8 \\
\hline 2 & 26.9 & 21.9 & 20.2 & 22.6 \\
\hline 3 & 35.3 & 31.6 & 28.9 & 29.2 \\
\hline 4 & 29.1 & 27.5 & 26.5 & 28.4 \\
\hline 5 & 23.0 & 22.3 & 23.3 & 25.5 \\
\hline 6 & 17.9 & 19.9 & 31.3 & 32.5 \\
\hline 7 & 11.9 & 13. 6 & 22.3 & 23.9 \\
\hline 8 & 9.0 & 9.6 & 15.4 & 17.0 \\
\hline 9 & 8.7 & 10.0 & 12.0 & 14.9 \\
\hline 10 & 8.0 & 9.6 & 11.4 & 14.0 \\
\hline 11 & 8.4 & 9.8 & 8.7 & 11.5 \\
\hline 12 & 8.2 & 10. 1 & 9.0 & 11.0 \\
\hline 13 & 7.6 & 10. 2 & 9.3 & 11. 1 \\
\hline 14 & 9.1 & 11.1 & 8.8 & 9.7 \\
\hline 15 & 8.3 & 10. 4 & 8.4 & 9.5 \\
\hline 16 & 7.9 & 9.7 & 8.5 & 9.7 \\
\hline
\end{tabular}

1) TO:Toyohashi inbred line( $\hat{\delta}) \times$ Okayama inbred line() ;OT: Okayama inbred line (o) $\times$ Toyohashi inbred line( ( +)

2) Expressed with a following equation: (Crossbreds means-Parental inbred lines means/Parental inbred lines means) $\times 100$

weeks of age for males and 2 to 7 weeks for females). MAEDA et al. ${ }^{8)}$ reported that heterosis effect in the early growth period resulted from an increase in fractional synthesis rate of protein due to crossbreeding between inbred lines. These results indicate that greater heterosis effect in the early growth period in the crossbreds may be due to an accelerated metabolic rate during the rapid growth period. However, no heterosis effect was found at 0 week (hatching time). BARBATo et al. ${ }^{11)}$ reported that hatching weight was influenced by maternal factors expressed through the well-known high dependency of chick weight on egg weight. Sefton et al. ${ }^{12)}$ and Marks ${ }^{13)}$ also found high correlation between hatching weight and egg weight in Japanese quail. Thus, it is considered that hatching weight of crossbreds was affected by the egg weight of the dam line, but not by paternal factors.

In comparison of the reciprocal crosses, a heavier body weight was observed in the female when Toyohashi inbred line (TT) was used as the female. In chickens, $\mathrm{YAO}^{14)}$, Friars et al. ${ }^{15)}$ and BARBATo et al. ${ }^{11)}$ showed that crossbred progeny from highweight dams were heavier than those from low-weight dams. A similar observation in turkey was reported by Buss et al. ${ }^{16)}$. HAzEL et al. ${ }^{17)}$, Goodwin et al. ${ }^{18)}$ and 
Table 2. The parameter values of Gompertz growth curve in inbred lines, their reciprocal crosses and randombred population of Japanese quail.

\begin{tabular}{|c|c|c|c|c|c|c|}
\hline \multirow{2}{*}{ Sex } & \multirow{2}{*}{ Group ${ }^{1)}$} & \multirow{2}{*}{$A^{2)}$} & \multirow{2}{*}{$b^{2)}$} & \multirow{2}{*}{$\mathrm{k}^{2)}$} & \multicolumn{2}{|c|}{ Inflection point } \\
\hline & & & & & Age(weeks) & Body weight (g) \\
\hline \multirow{5}{*}{ Male } & $\mathrm{OO}$ & $100.02^{\text {a } 3)}$ & $2.9941^{\mathrm{ab}}$ & $0.3350^{a}$ & $3.32^{\mathrm{a}}$ & $36.80^{a}$ \\
\hline & $\mathrm{TT}$ & $101.67^{a}$ & $3.0028^{a b}$ & $0.3285^{a}$ & $3.39^{a}$ & $37.40^{\mathrm{a}}$ \\
\hline & TO & $105.16^{b}$ & $3.0426^{\mathrm{a}}$ & $0.4056^{b}$ & $2.64^{\mathrm{b}}$ & $38.68^{\mathrm{b}}$ \\
\hline & OT & $108.07^{c}$ & $3.0563^{\mathrm{a}}$ & $0.4265^{\mathrm{b}}$ & $2.81^{\mathrm{c}}$ & $39.76^{c}$ \\
\hline & $\mathrm{RB}$ & 107. $21^{b c}$ & $2.9435^{\mathrm{b}}$ & $0.4592^{c}$ & $2.39^{d}$ & $39.44^{b c}$ \\
\hline \multirow{5}{*}{ Female } & $\mathrm{OO}$ & 118. $19^{a}$ & $3.0663^{\mathrm{a}}$ & $0.2994^{\mathrm{a}}$ & $3.86^{\mathrm{a}}$ & $43.48^{\mathrm{a}}$ \\
\hline & $\mathrm{TT}$ & $126.50^{\mathrm{b}}$ & 3. $1817^{\mathrm{b}}$ & $0.3172^{a}$ & $3.70^{a}$ & $46.54^{\mathrm{b}}$ \\
\hline & TO & $130.04^{\mathrm{bc}}$ & 3. $1971^{\mathrm{b}}$ & $0.3766^{\mathrm{b}}$ & $3.13^{b}$ & $47.84^{b c}$ \\
\hline & OT & $132.60^{\mathrm{c}}$ & $3.2293^{b}$ & $0.3702^{b}$ & $3.22^{b}$ & $48.78^{c}$ \\
\hline & $\mathrm{RB}$ & $132.76^{\mathrm{c}}$ & $3.0959^{a}$ & $0.4268^{c}$ & $2.67^{c}$ & $48.84^{\mathrm{c}}$ \\
\hline
\end{tabular}

1) OO: Okayama inbred line, TT: Toyohashi inbred line, TO: Toyohashi inbred line $(\hat{\delta}) \times$ Okayama inbred line (ㅇ), OT: Okayama inbred line $(\delta) \times$ Toyohashi inbred line (ㅇ) and $\mathrm{R} B$ : Randombred population.

2) $y=A e^{-b e^{-k t}}$ (Gompertz equation)

3) Values with different superscripts are signicantly different $(\mathrm{P}<0.05)$

WEARDEN et al. ${ }^{19)}$ also found the importance of maternal effects on body weight of chickens. These results are in agreement with the results of our study in Japanese quail. Thus, the reciprocal differences we have observed in body weight of the crossbred females may be partly due to maternal effects, although it is not clear why the effect does not appear in males. Possibly there may be participation of genes on W chromosomes.

In our study ${ }^{9)}$ on reproductive traits, it was found that crossing of highly inbred lines produced effective restoration of reproductive performance, such as viability and egg production rate, being similar to randombreds. However, the present investigation on the growth traits showed that the crossbreds did not overtake the randombreds. MERRITT et al. ${ }^{20)}$ reported that the relatively greater advantage of crossing breeds and strains was found for traits like egg production than for traits like body weight. $\mathrm{YAO}^{1)}$ also found the larger dominance effect for the highly variable characters, such as egg production and egg production rate compared with the highly heritable character, such as mature body weight. These results indicate that the relative superiority of the crossbreds is greater for reproductive traits which show lower heritability than for the growth traits which are high heritable.

Analysis with Gompertz equation showed that maximum size (A) and proportionality constant $(\mathrm{k})$ were higher in crossbreds than in inbred lines. Knizetova et al. ${ }^{3)}$ observed a sharper growth curve and a higher parameters for the growth rate in $\mathrm{F}_{1}$ hybrids between highly inbred lines of chicken. LAIRD et al. ${ }^{21)}$ also found a shift of the flexion point to an earlier age in hybrids of inbred lines of mice. Recently, AnTHONy et $a l .{ }^{22)}$ reported that some parameters of the growth rate showed higher 
values in lines selected for high body weight at 4 weeks of age than in lines selected for low body weight in Japanese quail. Our data also indicate that growth rate of the crossbreds of highly inbred lines was higher than that of parental inbred lines.

\section{Acknowledgments}

The authors are indebted to Miss Yuka Matsubara for extensive technical assistance.

\section{References}

1) YAO, T.S. (1961) Genetic variations in the progenies of the diallel crosses of inbred lines of chicken, Poult. Sci., 40 : 1048-1059.

2) Eisen, E.J., B.B. Bohren, H.E. McKean and S.C. King (1967) Genetic combining ability of light and heavy inbred lines in single crosses of poultry, Genetics, $55: 5^{-}$ 20 .

3) Knížetová, H., B. Kníže, J. Hyánek, R. Šller, L. Hyánková, J. Plachý and M. VILHEMOVÁ (1983) Growth curves of highly inbred lines of fowl and their $F_{1}$ hybrids, Génétique, Sélection, Evolution 15 : 533-558.

4) Abplanalp, H., S. Окамоto, D. Napolitano and R.E. Len (1984) A study of heterosis and recombination loss in crosses of inbred Leghorn lines derived from a common base population, Poult. Sci., $63: 234-239$.

5) Abplanalp, H., C. Tai and D. Napolitano (1984) Differences in body fat of six inbred lines of White Leghorns derived from a common base population, Poult. Sci., 63 : 418-424.

6) HAGGeR, C. (1985) Line and crossing effects in a diallel mating system with highly inbred lines of White Leghorn chickens, Theor. Appl. Genet., 70 : 555-560.

7) HAGGeR, C. (1986) Genetic effects of heterosis in $F_{1}$ and backcrosses of inbred lines of White Leghorns, Z. Tierzuchtg. Zuchtgsbiol., 103: 26-32.

8) Maeda, Y., K. Sato, S. Okamoto and T. Hashiguchi (1988) Heterosis in the body weight and muscle protein turnover rate in the Coturnix quail, Biochem. Genet., $26: 395-399$.

9) Sato, K., H. Fukuda, Y.E. Hedianto and T. Ino (1989) Heterosis for reproductive traits in reciprocal crosses of highly inbred lines of Japanese quail, Jpn. Poult. Sci., 26 : 70-73.

10) Snedecor, G.W. and W.E. Cochran (1980) Statistical Methods: 7th ed. the Iowa State Univ. Press, Ames, Iowa, U.S.A.

11) Barbato, G.F., P.B. Siegel and J.A. Cherry (1983) Inheritance of body weight and associated traits in young chickens, Z. Tierzüchtg. Züchtgsbil., 100 : 350-360.

12) Sefton, A.E. and P.B. Siegel (1974) Body weight relationships of newly hatched Japanese quail, Poult. Sci., 53 : 1254-1256.

13) Marks, H.L. (1975) Relationship of embryonic development to egg weight, hatch weight, and growth in Japanese quail, Poult. Sci., 54 : 1257-1262.

14) YAO, T.S. (1959) Additive and dominance effects of genes in egg production and 10-week body weight of crossbred chicken, Poult. Sci., 38 : 284-287.

15) Friars, G.W., F.N. Jerome, L.T. Weeden and G.C. Ashton (1963) Body weights and reproduction traits of two strains and reciprocal crosses of Broad Breasted Bronze turkey, Poult. Sci., 42 : 935-940.

16) Buss, E.G. and R.O. Hawes (1962) A "maternal effect" on body weight in turkey, Poult. Sci., $41: 1632$.

17) Hazel, L.N. and W.F. Lamoreux (1947) Heritability, maternal effects and nicking in relation to sexual maturity and body weight in White Leghorns, Poult. Sci., 26 : 508-514.

18) Goodwin, K., W.F. Lamoreux and G.E. Dickerson (1964) Maternal effects in 
chickens: Performance of daughters from dams of differing age, Poult. Sci., 43 : 1435-1442.

19) Weaeden, S., D. Tindell and J.V. Craig (1965) Use of a full diallel cross to estimate general and specific combining ability in chickens, Poult. Sci., 44: 10431053.

20) Merritt, E.S. and R.S. Gowe (1960) Combining ability among breeds and strains of meat type fowl, Can. J. Genet. Cytol., 2 : 286-294.

21) LAIRD, A.K. and A. Howard (1967) Growth curves in inbred mice, Nature, 213 : 786-788.

22) Anthony, N.B., K.E. Nestor and W.L. Bacon (1986) Growth curves of Japanese quail as modified by divergent selection for 4 -week body weight, Poult. Sci., 65 : 1825-1833.

\author{
ニホンウズラの高近交系間の正逆交雑種 \\ における成長のヘテロシス \\ 佐藤勝紀・福田弘之・前田芳實* \\ ヘディアントヤヌアルソエディ・猪 貴義 \\ 阔山大学農学部 岡山市 700 \\ * 鹿児島大学農学部 鹿児島市 890
}

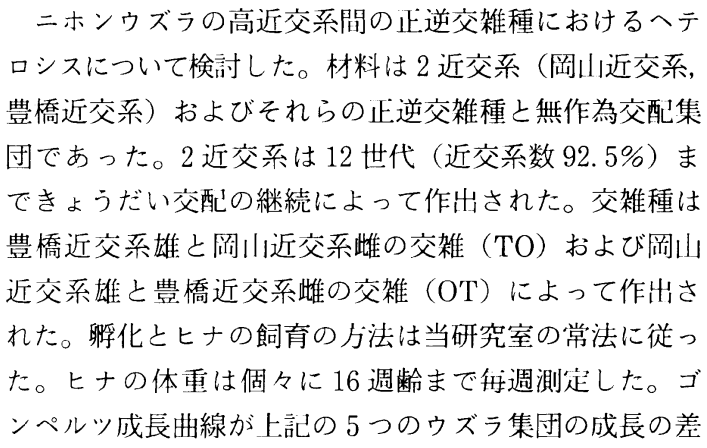
異を解析するため適用された。

止逆交雑種では, 成長のへテロシス効果が成長過程全
般において認められた。へテロシスの効果は特に, 初 期の成長段階（雄では 1〜 5 週齿, 雌では 2〜 週齢）で 顕著であった。しかし，0週龄時（孵化時）ではみられ なかった。特に, 雌の体重では, 正逆交雑種（TO, OT） の閣で差異が観察された。この差異は一部母性効果に起 因することが示唆されだゴンペルッ成長曲線を用いた 解析によって, 高近交系間の交雑種での成長速度はその 起源となった近交系の場合に比較して成長過程全般にわ たって優れていることが明らかになった。

（家离会誌，26：93～100, 1989） キーワード : ヘテロシス, 成長, 正逆交雑, 近交系, 二 ホンウズラ 